\title{
Homicides of black people in Brazil: A study of different regions, using generalized additive regression models-with a geo-spatial component
}

\author{
Elisângela Aparecida da Silva Lizzi, Marcos Vinicius Graciano Garrido, \\ Larissa da Silva Xavier, Gessieli Paloma de Moraes
}

Federal University of Technology, Paraná (UTFPR), Cornélio Procópio city (PR), Brazil

\begin{abstract}
The number of homicides in Brazil has reached record numbers, and when the race/colour of the victims is considered-an extreme inequality is evident- with a particularly high number of deaths in black and brown populations. The goal of this work was to analyse homicide rates of black people in Brazil from the years 2000 to 2016, using generalized additive regression models, with a geo-spatial component. The statistics were applied to
\end{abstract}

Correspondence: Elisângela Aparecida da Silva Lizzi, Federal University of Technology, Paraná (UTFPR), Cornélio Procópio city (PR), Brazil.

Tel.: (0055016) 99784.4405/(005543) 3132.1542.

E-mail: elisangelalizzi@utfpr.edu.br

Key words: Homicide; black population; spatial analysis; statistical models; Brazil.

Acknowledgements and funding: financial support of the Federal Technological University of Paraná - UTFPR, Brazil to carry out research of the course conclusion work (TCC) for the Mathematics Degree, according to the edict $01 / 2019$ by Pró-Reitoria de Relaçôes Empresariais e Comunitárias e PróReitoria de Graduação e Educação Profissional (PROREC/PROGRAD).

Contributions: MVGG, was the mastermind of this study to try to understand the situation of homicides in the black population in the different federal units in Brazil from 2000 to 2016 relating this with some indicators of interest and the historical context of the black population under advisor Adjunct Professor EASL. A consolidation of this study was made in the format of a presentation for conclusion work in the undergraduate course in mathematics degree, at the Federal Technological University of Paraná, Cornélio Procópio campus - PR. LdX and GPdM are part of the same research group and work in writing and consolidation of this paper.

Received for publication: 9 December 2020.

Revision received: 29 March 2021.

Accepted for publication: 29 March 2021.

(C) Copyright: the Author(s), 2021

Licensee PAGEPress, Italy

Geospatial Health 2021; 16:966

doi:10.4081/gh.2021.966

This article is distributed under the terms of the Creative Commons Attribution Noncommercial License (CC BY-NC 4.0) which permits any noncommercial use, distribution, and reproduction in any medium, provided the original author(s) and source are credited. understand the social reasons for homicide risks in the black population in Brazil's 26 states and Federal District with reference to the human development index and its components (education, longevity and income) as well as social inequality indices (Gini and Theil). This socioecological, epidemiological study to estimate the risk of homicide in the black population with a time series component, shows that this risk has increased linearly over time. Less longevity and low income correlated with a greater risk of homicide-while the Gini and Theil indices showed that in places where there are greater inequalities, there is also a higher risk of homicide in both black and non-black populations. The results - regarding the possibility of relating social indicators to homicide risk in the regional units under study, would support implementation of interventional public policy measures.

\section{Introduction}

Around 89,000 violent deaths were recorded worldwide in 2018, a 4\% increase compared to the previous year. This increase occurred mainly in Brazil, Mexico and Venezuela (Rossi \& Alessi, 2019). While the latter country is in a serious social crisis, which has led to increased crime and violent action involving paramilitary groups (Rossi \& Alessi, 2019), Brazil and Mexico suffer from the problem of organized crime and drug trafficking, with the poorest communities bearing most of the consequences. According to the World Health Organization (WHO), the definition of violence is: 'the intentional use of physical force or power, by threat or action, against yourself, another person or a group or community, which results or is highly likely to result in injury, death, psychological suffering, poor development or deprivation' (WHO, 2010). Violence consists of human actions by individuals, groups, classes and nations causing death of human beings or affecting individual person's physical, moral, mental or spiritual integrity (WHO, 2010; Minayo \& Souza, 1997). Worldwide, six homicides occur on average per 100,000 people, $50 \%$ of which committed with firearms (Igarapé, 2017). A high proportion of all homicides (around 66\%) take place in Latin America and the Caribbean (Instituto Igarapé, 2017).

The evolution of homicides in recent years in Brazil has reached record numbers. In 2015, there were more homicides in Brazil than in many other countries added together (WHO, 2015; UNODC, 2019). Brazil had the fourth highest homicide rate in South America, with 30.5 cases per 100,000 inhabitants, after Venezuela (51.7), Colombia (48.8) and Trinidad \& Tobago (32.80), while Chile (4.6), Argentina (4.7), Paraguay (7.5) and Uruguay (7.6) had the lowest homicide rates in this part of the 
world (WHO, 2015). When race/colour is considered, there is an even more extreme inequality, where Brazil has always occupied one of the top positions reflecting the fact that the country is considered as one of the most violent countries in the world (Waiselfisz, 2012). According to 2017 data in the Atlas of Violence (Cerqueira et al., 2019), 75.5\% of homicide victims were black individuals, with the homicide rate per 100,000 blacks being 43.1, whereas for non-blacks it was 16.0. So for every non-black individual who suffered homicide in 2017, approximately 2.7 blacks were killed.

For a better understanding of the social reality of today, it is necessary to also consider racism and its roots, which go back to the time between the $16^{\text {th }}$ and $19^{\text {th }}$ centuries after the arrival of approximately 5 million Africans who were brought to Brazil by the Portuguese through the slave trade (Pereira, 2018). In the period that followed the abolition of slavery in 1888 , the now freed slaves were marginalized, both in urban and rural areas, due to the scarcity of public actions aimed at integrating them into society, and they continue to be marginalized today (Marcussi, 2018). The abolition only reflected the legal aspect of freedom, and previous slaves and their descendants remained socially inferior, with very few of them achieving any degree of social mobility in addition to their freedom. To this day, they continue to occupy the lowest level of the Brazilian social pyramid (Marcussi, 2018).

Data from the summary of social indicators of 2019, provided by the Brazilian Institute of Geography and Statistics (IBGE), show that black and brown women stand out among the poor. Figures from 2019 show that although being a minority of the population $(28.7 \%$ ), these women number $38.1 \%$ of the poor and $39.8 \%$ of the extremely poor. This is due to the fact that they not only suffer discrimination in general, but also in the labour market where $32.0 \%$ of 15 to 29 years old black or brown women are uneducated and unemployed, compared to young, white people in the same situation $(13.2 \%)$. This underlines the great inequity that impedes assimilation. Indeed, historians and researchers work with the premise that blacks have been intentionally excluded from society that was, and still is, dominated by the white population, e.g., by incentives for European migration intended to achieve whitewashing of the population (Ribeiro, 2015).

Against this background, racism can be seen as something allied to an ideology, leading to difficulties for the black population concerning various activities, such as access to land ownership and the investment needed for education. People and ideologies are factors that have fostered the discrimination resulting in a situation forcing blacks in Brazil to live on the margins of society (Marcussi, 2018; Pereira, 2018). This historical process has been blamed for the high homicide rate in the black population that is almost three times greater than that involving whites, a bias that has been characterized as genocide and therefore necessitating a thorough investigation and discussion (Flores, 2016; Quirino, 2017). Black people also constitute the majority in the prison inmates due to mass incarceration (Santos et al., 2020), which is rooted in underemployment and trafficking that often appear as the only remaining job options in an extremely limited list of opportunities for those who are young and black in Brazil (Flores, 2016).

Brazil comprises 26 states, plus the Federal District with the capital city that together make up its 27 federative units (FUs). Article 3, item III in the federal constitution calls for eradication of poverty and marginalization and affirms the reduction of social and regional inequalities, whilst Article 3, item IV demands promotion of the good for all, without prejudice as to origin, race, colour, sex, age or any other form of discrimination. However, the social and economic indicators vary in relation to each state's public policies (Jannuzzi, 2016), an inequality which is related to socioeconomic factors and local social determinants.

The objective of this study was to investigate and verify the association between indexes by inequality social and development, which impact homicides in the black population. To this end, we produced thematic maps of homicide rates in this specific population and discuss these results in the light of the historical context of the black population.

\section{Materials and methods}

\section{Study design}

Using a time scale covering the period 2000-2016, we planned a socioecological study of the relationship between indices of inequality of social and development on the one hand, and homicides in the black population on the other. To reach these objectives, we involved the human development index (HDI) and its components education, longevity and income as well as the Theil and Gini indices of inequality. We also applied generalized additive regression modelling together with a geospatial component to allow a geographical weighting of the homicide risk.

The HDI is a summary metric of average achievement in key dimensions of human development: a long and healthy life (longevity), being knowledgeable (education) and having a decent standard of living (income). As mentioned in the Human Development Report (HDR), these are useful criteria for assessing the development of a country beyond just economic growth (HDR, 2019). The Theil index (1967) is a measure of the difference between the maximum possible entropy and the observed entropy of wealth distribution. The maximum possible entropy corresponds to complete equality in the distribution of wealth, i.e. where all people have the same (positive) economic standing. The extreme opposite case, complete inequality, is when one individual has all the wealth and all others nothing (Costa \& Pérez-Duarte, 2019). The Gini coefficient (1912) can be understood as the normalized absolute mean difference between all pairs of wealth in the population. This index is equal to zero in the case of total equality, that is when all people have the same (positive) wealth, and when we $>0$, various degrees of inequality in the distribution of wealth is indicated (Costa \& Pérez-Duarte, 2019)

\section{Study population and data sources}

Information on homicides of the FUs in the period 2000 to 2016 was obtained from the Brazilian Institute for Applied Economic Research (IPEA) and from the Atlas of Violence (IPEA, 2017; Cerqueira et al., 2019) using the following filters: violence by race and gender; homicides of black men; homicides of non-black men; homicides of black women; and homicides of nonblack women. The scope of this analysis refers to homicide data for the black population in Brazilian territory, stratified by FU and gender for the period 2000 to 2016 where the term 
'black' refers to both black and brown categories of people as standardized by IBGE.

The values of the social indicators are from the 2010 census, which allows extraction considering the HDI and its three components (education, longevity and income), the social inequality indices Gini and Theil, calculated according to the report of the United Nations Development Program (UNDP) given by HDR (2019). Estimates of population in UFs in Brazil by sex and race were obtained through TABnet (http://tabnet.datasus.gov.br/cgi/ deftohtm.exe?ibge/cnv/projpopuf.def), which provides population data according to official IBGE methods and statistics. The vector shapefiles that illustrate spatial information validated by maps were obtained directly from the IBGE website. After obtaining the required data from the different platforms, a preprocessing step was taken to eliminate duplicate information, after which the content was validated for analysis. The final database used was formatted and presented as a matrix structure by Microsoft Excel with focus on the multiple variables of interest. The maps were made by enabling connection between this database and the shapefiles storing the geographical information.

\section{Statistical analysis}

The generalized, additive geo-spatial regression models used had specific components to measure aspects related to geographic information systems (GIS), which are widely used in credibility models in various areas, such as finance (Bozkurt et al., 2018), crime (Marchant et al., 2018), traffic (Do et al., 2019), climate (Lima et al., 2016) and epidemiology (Martinez et al., 2020). Its advantage lies in the possibility to allow addition of geo-demographic variables and concepts of spatial smoothing. Another advantage of this approach refers to it being a model of the class of generalized linear models (MLG). The embedded GIS component referring to geographical location was utilized by associating the variables of interest with the latitude and longitude of the centroid of FU. In other words, a joint scenario was established where outcomes related to the homicide within the black population were incorporated together with geographical location and social, economic and socio-demographic covariates. The equation below refers to the generalized additive model used in this work:

$\log \left(Y_{i t}\right)=\alpha+f(t$-time $)+f($ social indicators $)+f($ rate of homicides non-black people) + flag(latitude, longitude)

where $\log \left(Y_{i t}\right)$ is the relative risk of homicide of black people $\left(Y_{i t}\right)$ in the $i^{\text {th }} \mathrm{FU}(i=1, \ldots, 27)$ and the $t^{\text {th }}$ year $\left(t_{1}=2000\right.$ to $\left.t_{17}=2016\right)$; $\alpha$ the intercept of the model, that is the mean parameter of the equation. The three HDI components (longevity, income and education) together with the Theil and Gini indices make up covariates together with homicides of nonblack people and interpolated by the spline component in relation to the behaviour of association with $Y_{i t}$ over time; and flag (latitude, longitude) is the component relative to the geographic position of the state centroid acting as weight for the spatial effect of the additive model. The rate of homicides in the FUs per 100,000 inhabitants was used as input.

Since this was an ecological analysis, the covariables were inserted into the models one by one to avoid problems of collinearity and estimation bias (Morgenstern, 1995). The model assumes that homicides of the black population follow a Poisson distribution with a logarithmic link function. There were other probability distributions tested, but this one obtained a better adjustment according to the deviance criterion (Spiegelhalter et al., 2014), a measure of discrimination and choice of the best model based on the results with the least variability. A spline smoother, defined as a curve constructed from sections of cubic polynomial, joined together so that the curve is continuous until the second derivative, was used (Wood, 2017). This refers to the function $f$ and means that a spline regression was obtained from each covariate and shown as a spline adjustment graph, which should be interpreted as follows: when the estimated risk is around zero, it has not changed; if greater than zero and showing a pattern, it is increasing; if less than zero and when the estimated risk is around zero, it has not changed; if greater than zero and showing pattern, it is decreasing. The confidence band of the main function corresponds to the confidence interval of the spline smoothing with $95 \%$ confidence.

The assumptions of the statistical theoretical model are based on homoscedasticity (constant variance) and normality of the residuals; both criteria were checked using hypothesis testing and graphs to make inferences. In all analyses, the level of significance was fixed at $5 \%$ and the confidence intervals at $95 \%$. Ten statistical models were generated, the first five of which referring to the correlation of homicides of black men to each indicator, i.e. the HDI components longevity, income and education and the social inequality indicators (the Gini and Theil indices); the following five similarly dealing with the correlations of homicides of black women.

\section{Results}

The results are divided into two parts, one describing the maps, which gives a global view of the homicides in the black population in the Brazilian FUs, and the second the results of the generalized, additive model.

\section{Population thematic maps}

Figure 1 shows that there is a clear, increasing trend of homicides of black men in the northern, north-eastern and mid-western regions of Brazil, which contrasts to the South, where there is a relatively stable level. However, the level of homicides of nonblack men in the northern and north-eastern regions (maps not shown) has been highly stable over the years, while there is a fluctuating tendency in the mid-western and south-eastern regions. The highest homicide rates for non-black men occur in the South and this situation has been stable for a long time. There is thus a dividing line between the North, the Northeast and the Midwest on the one hand, and the South and the Southeast on the other, with respect to homicides of men related to ethnicity.

Figure 2 depicts the corresponding trends referring to homicides in the black female population, showing that the highest rates are in the North, the Northeast and the Southeast and the lowest in the South and the Midwest. With regard to homicides of non-black women (maps not shown), there is stability with the lowest rates in the northern, north-eastern and central western regions. This is in contrast to the states in the Southeast and the South that carry the highest homicide rates among non-black women and where few changes and trends have been observed. 

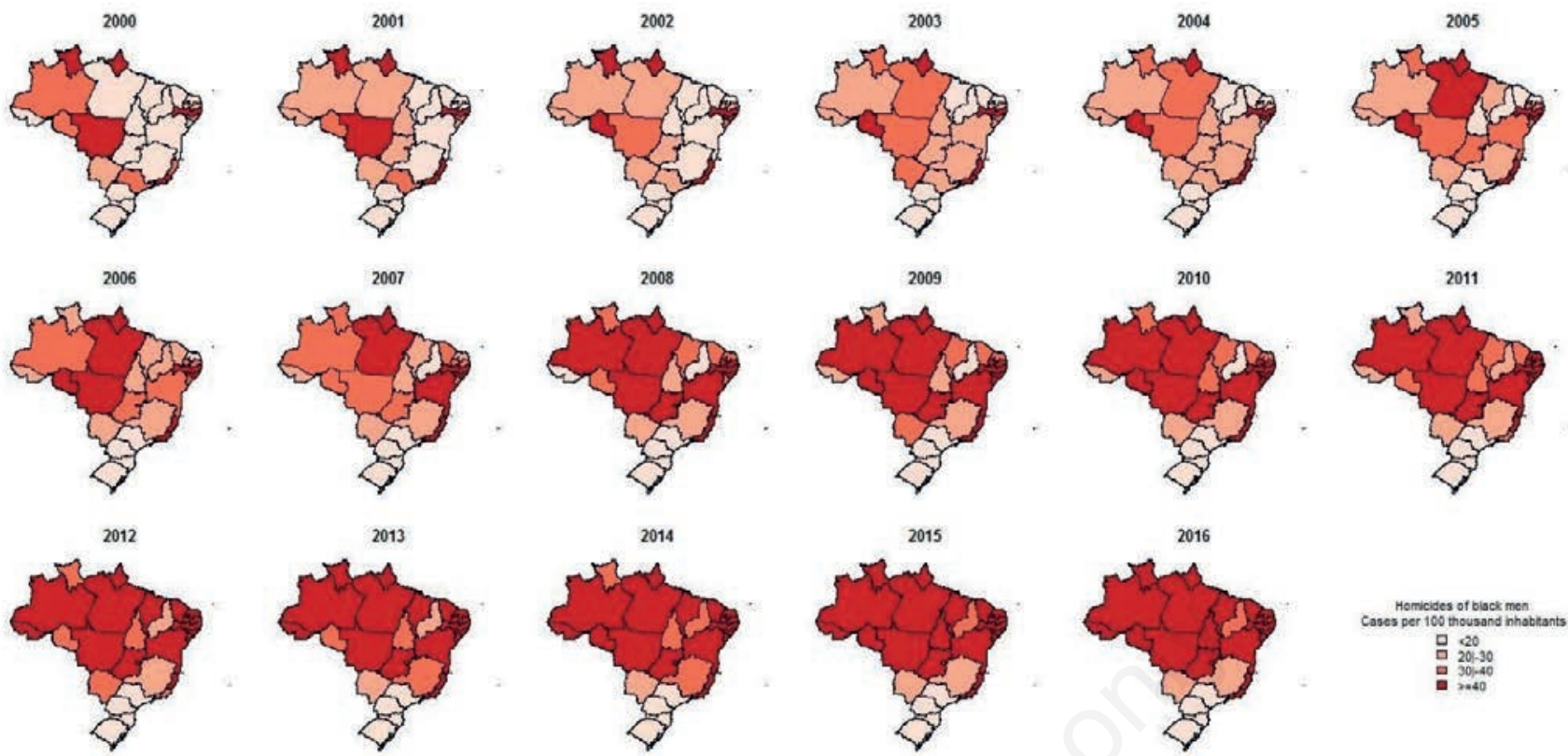

Moricides of bisck mon

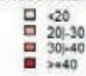

Figure 1. The changing temporal pattern of homicides in black men per 100,000 inhabitants in the period 2000-2016.
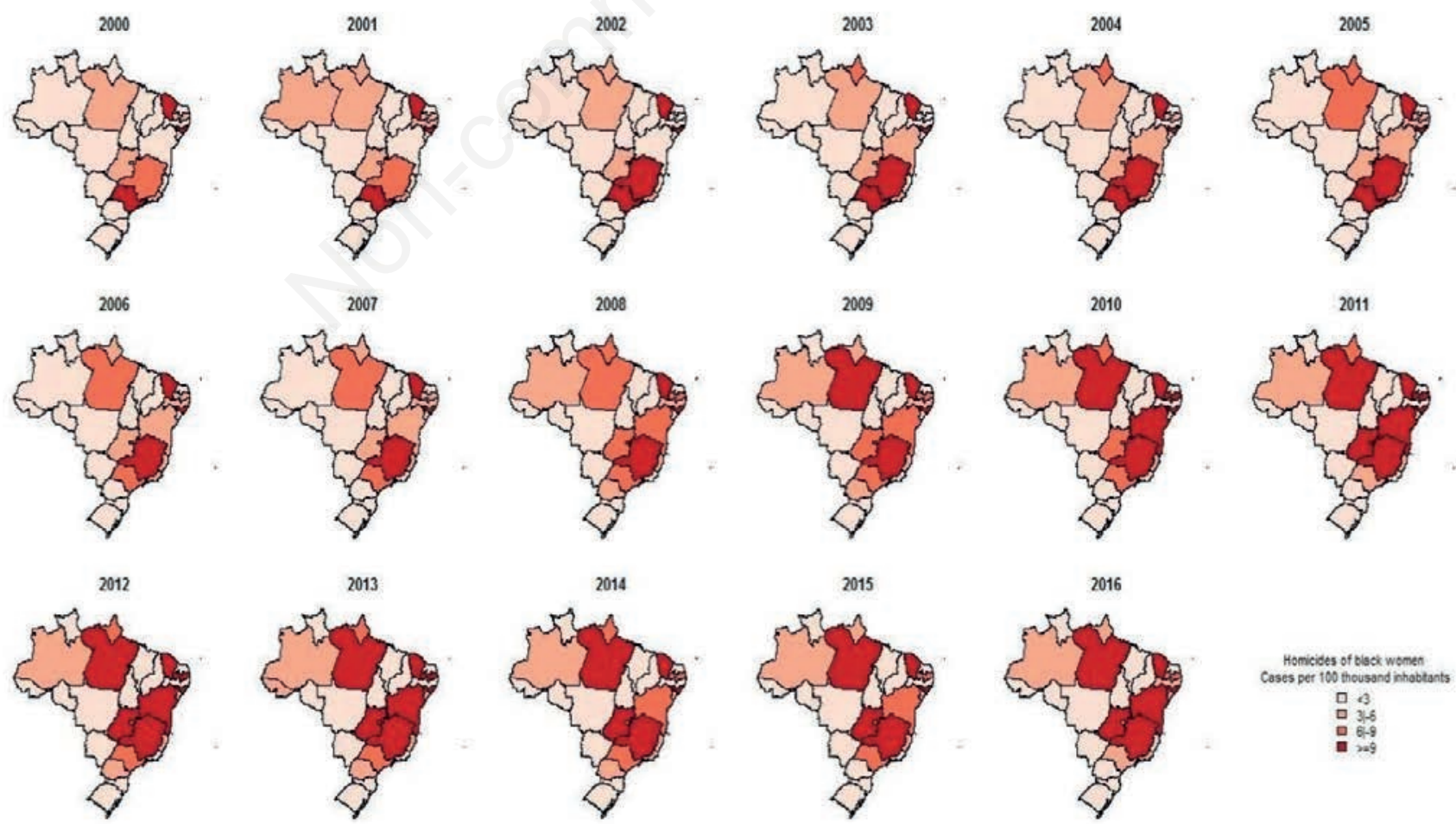

Figure 2. The changing temporal pattern of homicides in black women per 100,000 inhabitants in the period $2000-2016$. 
Therefore, in quantitative numbers tell us that the highest rates of female homicides are concentrated in the south-eastern region.

\section{Generalized additive model}

Table 1 shows the relationship of population rates in the FUs in 2010 (year of the census) with the different indicators investigated. The Theil index for Brazil stands at 0.68 , and it can be noted that the North $(0.70)$ and the North-east $(0.72)$ have high rates in contrast to the central-western $(0.60)$, southern $(0.49)$ and south-eastern $(0.58)$ regions. The Gini index gave a similar picture with 0.60 for the whole of the country with the highest values in the North (0.61) and the North-east (0.62), while the Midwest (0.57), the South (0.52) and the South-east (0.57) all resulted in low outcomes. In other words, the northern and north-eastern regions express greater social inequalities in terms of income distribution.

With regard to the HDI income component, the rate for all Brazil was 0.74, with the South (0.77), the South-east (0.76) and the Central-west $(0.77)$ showing the highest rates as opposed to the North (0.61) and the North-east $(0.65)$. For the longevity component, the rate for the whole country was 0.82 , with the South (0.84), the South-east (0.84) and the Central-west (0.84) providing the highest rates in contrast to the North $(0.80)$ and the North-east (0.78), which had the lowest. When we finally turned to the education component, the outcome for Brazil as a whole was found at 0.64 , while some regions, such as the South (0.67), the South-east (0.67) and the Central-west (0.66), all had high rates, in contrast to the North (0.59) and the North-east (0.59). In other words, the southern, south-eastern and mid-western regions expressed the highest values with regard to all three HDI components.

The statistical models show the risk pattern identified by the indicators in relation to their association with cases of homicide in Figure 3 with reference to the male population (models 1 to 5 ) and in Figure 4 with reference to the female population (models 6 to 10). The figures show the adjustments of the spline function for the different indicators under study with regard to the homicide risk.

Table 1. Description of the indicators studied by states and regions.

\begin{tabular}{|c|c|c|c|c|c|c|}
\hline Region & State (FU) & Theil & Gini & $\begin{array}{l}\text { ndicator } \\
\text { HDI-R }\end{array}$ & HDI-L & HDI-E \\
\hline South & $\begin{array}{l}\text { Rio Grande do Sul (RS) } \\
\text { Santa Catarina (SC) } \\
\text { Paraná (PR) } \\
\text { Overall }\end{array}$ & $\begin{array}{l}0.53 \\
0.42 \\
0.51 \\
0.49\end{array}$ & $\begin{array}{l}0.54 \\
0.49 \\
0.53 \\
0.52\end{array}$ & $\begin{array}{c}0.769 \\
0.773 \\
0.757 \\
0.77\end{array}$ & $\begin{array}{l}0.84 \\
0.86 \\
0.83 \\
0.84\end{array}$ & $\begin{array}{c}0.642 \\
0.697 \\
0.668 \\
0.67\end{array}$ \\
\hline Southeast & $\begin{array}{l}\text { São Paulo (SP) } \\
\text { Minas Gerais (MG) } \\
\text { Espirito Santo (ES) } \\
\text { Rio de Janerio (RJ) } \\
\text { Overall }\end{array}$ & $\begin{array}{l}0.57 \\
0.56 \\
0.56 \\
0.64 \\
0.58\end{array}$ & $\begin{array}{l}0.56 \\
0.56 \\
0.56 \\
0.59 \\
0.57\end{array}$ & $\begin{array}{c}0.789 \\
0.73 \\
0.743 \\
0.782 \\
0.76\end{array}$ & $\begin{array}{c}0.845 \\
0.838 \\
0.835 \\
0.835 \\
0.84\end{array}$ & $\begin{array}{c}0.719 \\
0.638 \\
0.653 \\
0.675 \\
0.67\end{array}$ \\
\hline Central - W & $\begin{array}{l}\text { Mato Grosso do Sul (MS) } \\
\text { Goiás (GO) } \\
\text { Federal District (DF) } \\
\text { Mato Grosso (MG) } \\
\text { Overall }\end{array}$ & $\begin{array}{l}0.57 \\
0.53 \\
0.76 \\
0.54 \\
0.60\end{array}$ & $\begin{array}{l}0.56 \\
0.55 \\
0.63 \\
0.55 \\
0.57\end{array}$ & $\begin{array}{c}0.740 \\
0.742 \\
0.863 \\
0.732 \\
0.77\end{array}$ & $\begin{array}{c}0.833 \\
0.827 \\
0.873 \\
0.821 \\
0.84\end{array}$ & $\begin{array}{l}0.629 \\
0.646 \\
0.742 \\
0.635 \\
0.670\end{array}$ \\
\hline North & $\begin{array}{l}\text { Rondônia (RO) } \\
\text { Acre (AC) } \\
\text { Amazonas (AM) } \\
\text { Pará (PA) } \\
\text { Tocantins (TO } \\
\text { Amapá (AP) } \\
\text { Roraima (RR) } \\
\text { Overall }\end{array}$ & $\begin{array}{l}0.56 \\
0.73 \\
0.8 \\
0.70 \\
0.68 \\
0.68 \\
0.75 \\
0.70\end{array}$ & $\begin{array}{c}0.56 \\
0.63 \\
0.65 \\
0.62 \\
0.6 \\
0.6 \\
0.63 \\
0.61\end{array}$ & $\begin{array}{l}0.712 \\
0.671 \\
0.677 \\
0.646 \\
0.690 \\
0.694 \\
0.695 \\
0.68\end{array}$ & $\begin{array}{l}0.800 \\
0.777 \\
0.805 \\
0.789 \\
0.793 \\
0.813 \\
0.809 \\
0.800\end{array}$ & $\begin{array}{l}0.577 \\
0.559 \\
0.561 \\
0.528 \\
0.624 \\
0.629 \\
0.628 \\
0.590\end{array}$ \\
\hline Northeast & $\begin{array}{l}\text { Bahia (BH) } \\
\text { Piauí (PI) } \\
\text { Maranhão (MA) } \\
\text { Ceará (CE) } \\
\text { Rio Grande do Norte (RN) } \\
\text { Paraíba (PB) } \\
\text { Pernambuco (PE) } \\
\text { Alagoas (AL) } \\
\text { Sergipe (SE) } \\
\text { Overall }\end{array}$ & $\begin{array}{l}0.73 \\
0.73 \\
0.74 \\
0.72 \\
0.68 \\
0.70 \\
0.74 \\
0.75 \\
0.72 \\
0.72\end{array}$ & $\begin{array}{l}0.62 \\
0.61 \\
0.62 \\
0.61 \\
0.60 \\
0.61 \\
0.62 \\
0.63 \\
0.62 \\
0.62\end{array}$ & $\begin{array}{l}0.663 \\
0.635 \\
0.612 \\
0.651 \\
0.678 \\
0.656 \\
0.673 \\
0.641 \\
0.672 \\
0.650\end{array}$ & $\begin{array}{l}0.783 \\
0.777 \\
0.757 \\
0.793 \\
0.792 \\
0.783 \\
0.789 \\
0.755 \\
0.781 \\
0.780\end{array}$ & $\begin{array}{l}0.555 \\
0.547 \\
0.562 \\
0.615 \\
0.597 \\
0.555 \\
0.574 \\
0.520 \\
0.560 \\
0.570\end{array}$ \\
\hline All of Brazil & & 0.68 & 0.60 & 0.74 & 0.820 & 0.640 \\
\hline
\end{tabular}

HDI-R, human development index-income; IDH-L, human development index-longevity; HDI-E, human development index-education. 


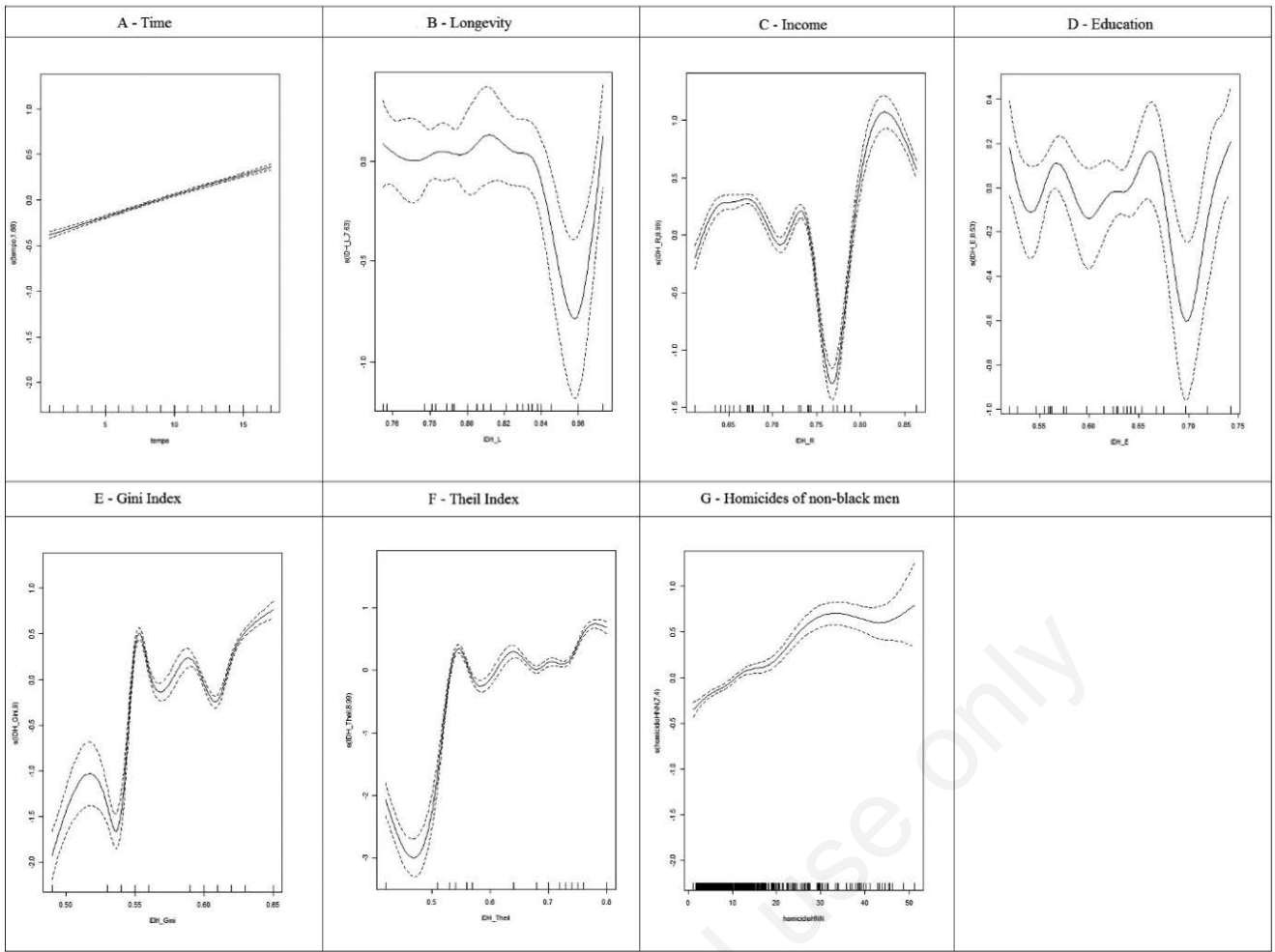

Figure 3. Graphs of the adjustment of the spline function for the models developed to study the male risk behaviour with respect to the indicators studied. Legend: The line in the centre is the function interpolated by the spline, the upper and lower lines are the confidence intervals of the estimate by $95 \%$.

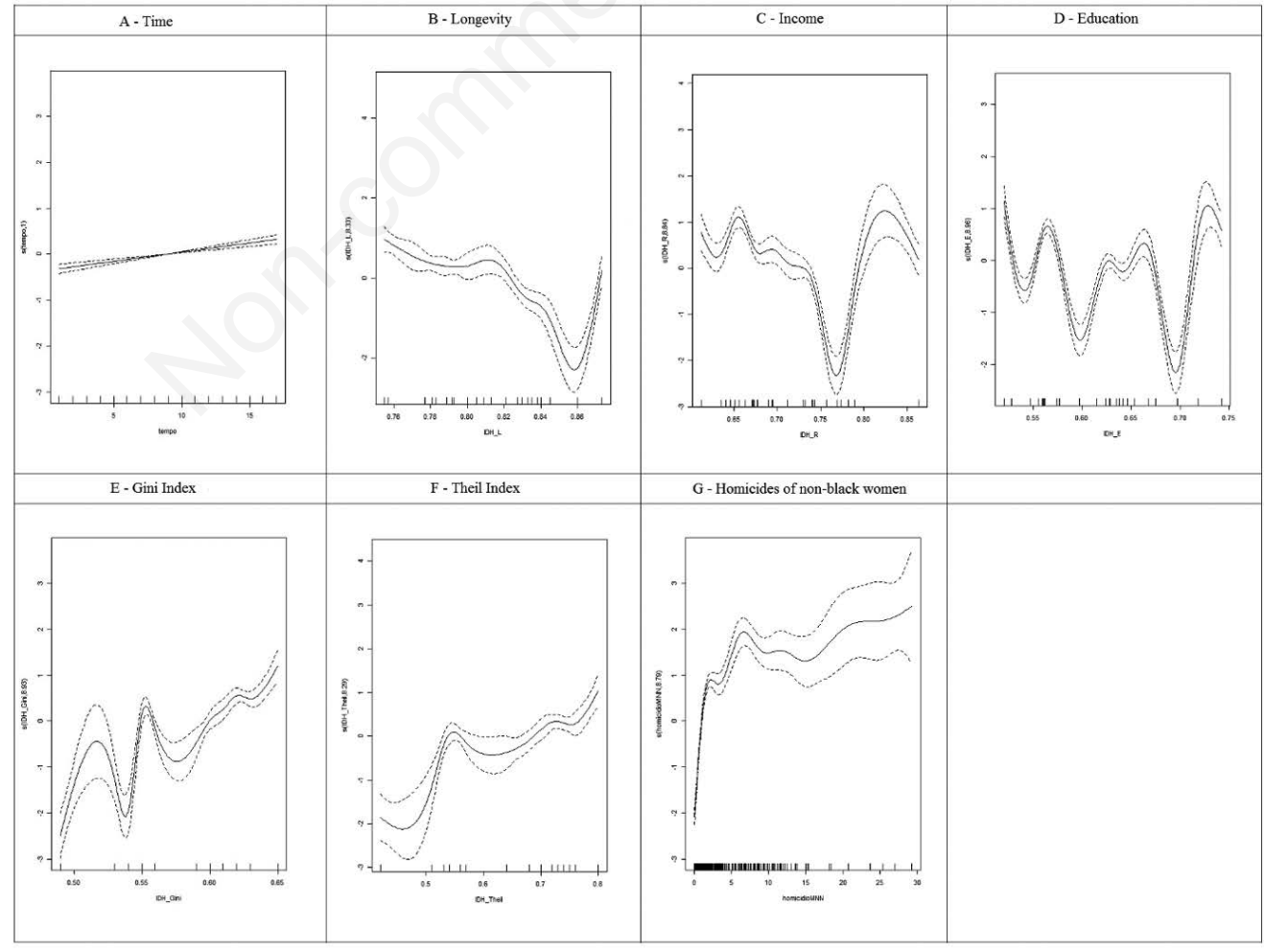

Figure 4. Graphs of the adjustment of the spline function for the models developed to study the female risk behaviour with respect to the indicators studied. Legend: The line in the centre is the function interpolated by spline, the upper and lower lines are the confidence intervals of the estimate by $95 \%$. 
Panel A in Figure 3 shows the development of homicides over time in the male population, where an increasing linear-type pattern is exhibited, which means that the number of homicides tends to increase over the years and they do not stabilize over the period studied $(\mathrm{P}<0.01)$. Model 1 (panel $\mathrm{B})$ shows the relationship between homicides and longevity, where it can be noted that homicides tend to approach zero on the $\mathrm{y}$-axis $(\mathrm{P}=0.01)$ after increasing, which means that the risk of homicide is greater for large values of longevity, that is in the states with greater longevity, the risk of homicides is higher. Model 2 (panel C) refers to the income component which plunges in relation to homicides in the southern region followed by an increase related to the south-eastern region $(\mathrm{P}<0.01)$. This plunge is caused by the state of São Paulo, whilst the rise is mainly due to high income as well as a high level of homicides in the state of Rio de Janeiro. In model 3 (panel D), which concerns the education component $(\mathrm{P}=0.01)$, we were unable to determine a relationship because the model had an oscillation and a non-specific pattern over time without an explainable potential at the level of the study. This pattern might be understood as related to the education component in a disaggregation by mesoregions or cities. Model 4 (panel E) shows the outcome of the Gini index $(\mathrm{P}<0.01)$ and model 5 (panel F) the Theil index $(\mathrm{P}<0.01)$. It can be noted that the higher the inequality, the greater the risk of the occurrence of homicides. Panel $G$ refers to homicide of non-black men in relation to social inequality (as indicated by the Gini and Theil indices) and shows a similar picture. Thus, inequality promotes homicide, both for black and non-black men. However, although inequality is shown to be significantly correlated to the level of homicide in both groups, it can be noted that the increase in risk is less pronounced with respect to non-black men.

Figure 4 shows the corresponding results of the models when applied to the female population, which are very similar to the results obtained with regard to male homicides. As seen in model 8 (panel D), we had the same problem with respect to education because the model's graph tended to oscillate $(\mathrm{P}<0.01)$.

\section{Discussion}

The research work presented here was planned to highlight the prejudice experienced by the black population in terms of the number of homicides. By applying statistical models to study the correlation of homicides within the black population in Brazil's FUs with indicators of human development and social inequality, our aim was not only to obtain a view of the occurrence of homicides in a numerical way, but also open a dialogue on the nature of the problem under study.

Prejudice and racism are closely related, with the former being a set of implicit associations unconsciously maintained about a certain group of people, and the latter defined as prejudice against individuals of a specific ethnicity that can be both explicit or implicit (Marmelstein, 2021). As racism is a distorted appropriation of reality, through which unaccepted characteristics are projected onto another human being, group or society (Martins, 1998), it is not possible to simply apply a metric index. Against this background we chose to evaluate the level of violence against the black population in Brazil by assessing the presence of homicide in different parts of the country.

The generalized, additive statistical regression models, including a spatial component, referred to in this paper were found useful in depicting the homicide trends in relation to the set of social indicators chosen. We noticed that homicides continued to increase in all models applied over the 16-year study period, and we saw that they followed an increasing linear pattern without stabilization at any level. We also found that where there was less longevity and lower income, there was also a greater risk of homicide. In addition, in places characterized by greater inequality (as indicated by the Gini and Theil indices), there was also a higher risk of homicide.

In contrast to longevity, income and inequality, it was not possible to distinguish a pattern in relation to homicides of black people with regard to education. This could be due to the model used not showing a specific pattern because of existing disparities in relation to the education within each FU. This could be overcome by using a higher level of disaggregation, e.g., by collecting information by city or mesoregion instead of basing the study at the FU level. Indeed, decentralization between the political powers (federal level, state and municipality) needs to be considered at a higher resolution with effective public security policies for each regional reality, such as at the municipality level or within municipalities in specific neighbourhoods or districts as pointed out by Beato Filho (1999). Another problem that could have affected this study is underreporting of violence, which is a common setback in social investigations (Minayo, 1994; Minayo \& Souza, 1997) potentially limiting the amount of data available for investigation.

When studying the results of homicide risk rates for nonblack men and women, we show that homicide risk in relation to income increases until a point (HDI-income $=0.83$ ) and then decreases in the highest values (rich states). Indeed, when considering the inequality indicators it was possible to verify that the risk of homicide in the non-black population increases for both genders just as it does for the black population. Undeniably, social inequality is the pivot of social violence (Minayo, 1994; Minayo \& Souza, 1997), and violence and inequality need joint coping policies to be successful in prevention, as confrontation by legal and political measures based on ineffective methods tend to aggravate the situation (Gomes et al., 2006). To improve this situation, intervention and action from various federal institutions is required, above all mobilization of organizations working in the areas of health, education, social assistance, urban planning and security (Beato Filho, 1999). Among effective actions in targeting violence are security programs and strategies based on multi-institutional articulation between state and society (Greenwood et al., 1996; Felson \& Clarke, 1997; Sherman, 1998; Short, 1997). Aiming at the promotion of subsidies for macroregional policy implementation strategies and surveillance, our work was based on aggregated population-based data (Gordis, 2004) without considering the individual level of information. Public policies must also take into account regional and social diversification, as well as paying attention to race as any strategy meets social demands in several sectors (Beato Filho, 1999). Allocation of resources must not only consider basic governmental priorities such as education, health and security, but also include efforts identifying places and groups within society deserving priority treatment. With respect to equity, it is necessary to promote research highlighting the problem using geographic monitoring as part of the solution. 


\section{Conclusions}

Generalized, geo-spatial, additive models with a time series component are useful to understand the social context of the homicide risk of the black population in Brazil. This should take place alongside a joint study of socio-economic and inequity indicators allowing for outlining strategies focused on the implementation of public policies against violence, with diversification by regional and intelligent support of decision models.

\section{References}

Beato Filho CC, 1999. Public security policies and the police issue. São Paulo Perspec 13:13-27.

Bozkurt I, Karakus R, Yildiz M, 2018. Spatial determinants of financial inclusion over time. J Int Dev 30:1474-504.

Cerqueira D, Lima RS, Bueno S, Neme C, Ferreira H, Alves PP, Marques D, Reis M, Cypriano O, Sobral I, Pacheco D, Lins G, Armstrong K, 2019. Atlas of violence. Institute for Applied Economic Research and Brazilian Forum of Public Security, Rio de Janeiro, Brazil, 72 pp. Available from: https://agenciabrasil.ebc. com.br/en/direitos-humanos/noticia/2019-06/violence-atlas-reveals-homicide-rate-brazil-42 Accessed: 21 March 2021.

Costa RN, Pérez Duarte S, 2019. Not all inequality measures were created equal - The measurement of wealth inequality, its decompositions, and an application to European household wealth. Statistics Paper Series 31, European Central Bank. Available from: https://ideas.repec.org/p/ecb/ecbsps/201931. html Accessed: 17 March 2021.

Do LN, Vu HL, Vo BQ, Liu Z, Phung D, 2019. An effective spatial-temporal attention based neural network for traffic flow prediction. Transport Res Part C Emerg Technol 108:12-28.

Felson M, Clarke R, (Eds.), 1997. Business in crime prevention. Criminal Justice Press, Monsey, NY, USA, 293 pp.

Flores T, 2016. Human Rights: different approaches. Chapter six. pp 109-125 in Brazilian Chamber of Young Writers, (Ed.), Genocide of Black Youth in Brazil: the new forms of war, race and coloniality of power. Human Rights: different approaches. Brazilian Chamber of Young Writers, Rio de Janeiro, Brazil.

Gini C, 1912. Variabilità e mutabilità. In: Pizetti E, and Salvemini T, (Eds.), Memorie di metodologica statistica. Libreria Eredi Virgilio Veschi, Rome, Italy, 01:211-382.

Gomes R, Minayo MCDS, Assis SGD, Njaine K, Schenker M, 2006. Successes and limits in preventing violence: a case study of nine Brazilian experiences. Sci Collect Health 11:397-408.

Gordis L, 2004. Epidemiology, 3rd edn. Elsevier, Amsterdam \& Philadelphia, 416 pp.

Greenwood PW, Model K, Rydell CP, Chiesa J, 1996. Diverting children from a life of crime: measuring costs and benefits. RAND Corporation, Santa Monica, CA, USA, 69 pp. Available from: https://doi.org/10.7249/RB4010

HDR (Human Development Report), 2019. Technical notes. Beyond income, beyond averages, beyond today: Inequalities in human development in the 21 st century. Available from: https://www. hdr.undp.org/sites/default/files/hdr2019_techni- cal_notes.pdf Accessed: 4 December 2020.

Instituto Igarapé, 2017. Homicide observatory: visualization tool shows the distribution, dimensions and dynamics of lethal violence in the world. Available from: https://www. igarape.org.br/apps/observatorio-de-homicidios/ Accessed: 18 June 2019.

IPEA (Brazilian Institute for Applied Economic Research), 2017. Atlas of violence, 2017. Consultation: violence by race and gene. Available from: http://www.ipea.gov.br/atlasviolencia/ filtros-series/3/violencia-por-raca-e-genero Accessed: 5 February 2019.

Jannuzzi PDM, 2016. Social indicators in the formulation and evaluation of public policies. Unidade de Ensino e Aprendizado de Viçosa, UNESAV, 9 p. Available from: https://www.nescon.medicina.ufmg.br/biblioteca/imagem/20 12.pdf

Lima RC, Moreira EBM, Nóbrega RS, 2016. The climatic influence on the dengue epidemic in the city of Recife by Geographic Information System. Braz J Phys Geogr 9:38498.

Marchant R, Haan S, Clancey G, Cripps S, 2018. Applying machine learning to criminology: semi-parametric spatialdemographic Bayesian regression. Secur Inform 7:1-19.

Marcussi AA, 2018. Anti-colonialism as a tragedy: "the black Jacobins" between history and politics. Cad Hist 19:95-122.

Marmelstein G, 2021. Discriminação por Preconceito Implícito. JusPodivm, Brazil, 144 pp.

Martinez EZ, Zucoloto ML, Galdino G, Nunes AA, Lizzi EADS, 2020. Spatiotemporal distribution of acquired immunodeficiency syndrome incidence in Brazil between 2012 and 2016. Rev Soc Bras Med Trop 53:1-5.

Martins MM, 1998. Reflections on prejudice-in search of more human relationships. Interação Psicol 2:3-19.

Minayo MCDS, 1994. Social violence from the perspective of public health. Cad Saúde Públ 10:7-18.

Minayo MCDS, Souza ERD, 1997. Violence and health as an interdisciplinary and collective action field. Hist Ciens Saúde-Manguinhos 4:513-31.

Morgenstern H, 1995. Ecologic studies in epidemiology: concepts, principles, and methods. Annu Rev Public Health 16:61-81.

Pereira MI, 2018. The historical construction of racism in Brazil. Estado de Mina, Bras J Est Min. Available from: https://www.em.com.br/app/noticia/especiais/abolicao130an os/2018/05/11/noticia-abolicao130anos,957834/a-construcao-historica-do-racismo-no-brasil.shtml\#: :text $=$ Racismo $\% 20 \% \quad$ C3 $\%$ A $9 \% 200 \% 20$ preconceito $\% 20 \mathrm{e}, \mathrm{os} \%$ 20s\%C3\%A9culos\%2016\%20e\%2019 Accessed: 4 December 2020.

Quirino KTM, 2017. Frameworks and advocacy on the genocide of young black people: analysis of the coverage of Folha de S. Paulo. University of Brasilia, 306 pp.

Ribeiro D, 2015. O povo brasileiro: a formação e o sentido do Brasil. Global, Brazil, 328 pp.

Rossi M, Alessi G, 2019. El Country: Brazil, Mexico and Venezuela are pushing the rise in global homicides. El País, Brazil. Available from: https:/www.brasil.elpais. com/brasil/ 2019/06/05/politica/1559762691_083450.html Accessed: 4 December 2020.

Santos RR, Barreto Júnior JAS, Melo MLA, 2020. Mass incarceration of the black population in Brazil: analysis of the 
ineffectiveness of the impersonality principle of penal rules in face of the incarceration policies in the Soteropolitano Penitentiary System. Universidade Católica do Salvador, Brazil, 157 pp.

Sherman L, 1998. Thinking about crime prevention. In: Sherman LW, Gottfredson DC, MacKenzie DL, Eck J, Reuter P, Bushway SD, (Eds.), Preventing crime: what works, what doesn't: what's promising, 19 pp. U.S. Department of Justice, National Institute of Justice - News in Brief; July 1998.

Short Jr JF, 1997. Poverty, ethnicity and violent crime. Routledge/Taylor and Francis, London, UK, 259 pp.

Spiegelhalter DJ, Best NG, Carlin BP, Van der Linde A, 2014. The deviance information criterion: 12 years on. J Royal Stat Soc Series B Stat Methodol 76:485-93.

Theil H, 1967. Economics and information theory. Studies in mathematical and managerial economics, Vol. 7 (pp. xxii + 488 pp). Amsterdam, North Holland.

UNODC (United Nations Office on Drugs and Crime), 2019.
Global study on homicide: Executive summary. Available from: https://www.unodc.org/documents/data-andanalysis/gsh/Booklet1.pdf

Waiselfisz JJ, 2012. Map of violence: the color of homicide in Brazil. 41 pp. Centro Brasileiro de Estudos LatinoAmericanos, FLACSO Brasil, Secretaria de Políticas de Promoção da Igualdade Racial, Governo Federal do Brasil, Brasilia, Brasil.

WHO (World Health Organization), 2010. Violence prevention: the evidence. World Health Organization, Geneva, Switzerland, 134 pp. Available from: https://apps.who.int/ violence-info/about Accessed: 4 December 2020.

WHO (World Health Organization), 2015. Violence infor: Homicide: WHO Global Health Estimates. Available from: https://apps.who.int/violence-info/homicide

Wood SN, 2017. Generalized additive models: an introduction with R. Chapman and Hall/CRC/Taylor and Francis, Boca Raton, FL, USA, 496 pp. 